\title{
Balance of Power: The Governance Structure of International Branch Campus in China
}

\author{
Yanhao Wang \\ Seton Hall University, United States \\ Email: yanhao.wang@student.shu.edu. \\ Address: Seton Hall University, NJ, United States
}

\section{Introduction}

An international branch campus is an "off-shore operation of a higher education institution which is operated by the institution or through a joint-venture in which the institution is a partner and is in the name of the foreign institution" (Verbik 2007). Branch campuses in China, recently, have become a heated topic, not only because China is one of the most important receiving countries and holds more than 40 branch campuses (Cross-Border Education Research Team 2017), but also because some studies or news are concerning about the academic freedom or autonomy at those institutions (Altbach 2013; Redden 2019).

One important feature of branch campuses in China is that they are mandated by China government to collaborate with local institutions (Huang 2008). Scholars have agreed that the organizational structures and relationships between partners contribute to the sustainability or academic freedom of branch campuses (Altbach 2013; Borgos 2016; Franklin and Alzouebi 2014). The relationship between the home campuses and local partners (local universities or government), therefore, appears as an important issue.

This research studies three Sino-US branch campuses: New York University (NYU)-Shanghai, Duke-Kunshan University (DKU), and Wenzhou-Kean University (WKU). NYU-Shanghai cooperates with East China Normal University and the Shanghai government. DKU works with Wuhan University and the Kushan local government. WKU collaborates with Wenzhou University but also gets supports from the Chinese Central government. The three branch campuses were established after 2012 when the Ministry of Education of China published new policies to standardize international cooperation, so they could reflect the current trends and policies. In this research, I am examining the governing boards and senior leaderships of these universities to study the authorities and roles of different partners and how the universities balance the power of home campuses and local partners.

The primary method I am using is qualitative document analysis (Bowen 2009), which is popular in organization or higher education analysis (Al Khafaji 2018; Hou et al. 2018; O'Donnell 2016; Owen 2014). The main sources of my data are official websites and faculty handbooks, from which I will acquire the basic design of the boards or senior leaderships, the responsibilities of different positions, and the background of the leaders. I also am using complementary resources like government policies, news reports and interviews for more information or evaluation from relevant people, such as the president of NYU Shanghai, the chancellor of DKU, and the Minister of Education of China.

Bacharach and Lawler's (1980) modes are applied to identify the power holders and based on the results, I will first describe the structures, such as the design of positions, to see how they reflect the cooperation or balance of power between home and local institutions. Then I will analyze the appointment of the power holders to see if they represent American home universities or Chinese partners. Next, I will compare these three institutions in order to find and explain the common features and differences. Finally, I will conclude and evaluate the campuses' strategies to balance the powers and meet to local requirements. 
Currently, I already completed analyzing DKU and am now working on analyzing NYU-Shanghai and WKU. Two distinctive facts could be found from DKU: first, the local government plays an important role in its senior leadership and the board of trustees. Second, DKU highlights its relationship with government so it has a vice chancellor of government relations. The development plan of Kunshan local government may contribute to these features. Additionally, both DKU and NYU-Shanghai keep a balanced proportion of Chinese and American leaders in their senior leaderships and oversighting boards, while WKU has only two leaders appointed by Kean University and five senior leaders of Chinese background. The reasons and effects of these different types of leadership will be a part of this research.

Although international campus in China has received attention and several scholars examined governance of these institutions (Helms 2008) or strategy (Shams and Huisman 2012), few researches focus on the power balance of various partners. This research, therefore, could provide fresh data and conclusion for the research of international higher education. The main takeaway will include a description and evaluation of different strategies to balance the powers of home campuses and local partners, which could be helpful to understand how host countries' policies could affect foreign institutions' organization and what structures could be adopted to facilitate the development of international campus. It also helps both host and home countries to rethink then develop their strategies. The results, enhancing the transparency of higher education, could even be used by students choose the institution to attend.

\section{References}

Al Khafaji, Nicole. 2018. "International Branch Campuses: A Qualitative Study of Cross-Cultural Training." PhD diss., Northcentral University.

Altbach, Philip G. 2013. "Is There a Future for Branch Campuses?" In The International Imperative in Higher Education, 101-106. Rotterdam: Sense Publishers.

Bacharach, Samuel B., and Edward J. Lawler. 1980. Power and politics in organizations. San Francisco: Jossey-Bass.

Borgos, Jill. 2016. "Addressing Sustainable International Branch Campus Development Through an Organizational Structure Lens: A Comparative Analysis of China, Qatar, and the United Arab Emirates." Chinese Education \& Society 49(4-5): 271-287. https://doi.org/10.1080/10611932.2016.1237849.

Bowen, Glenn A. 2009. "Document Analysis as a Qualitative Research Method." Qualitative Research Journal 9(2): 27-40. https://doi.org/10.3316/QRJ0902027.

Cross-Border Education Research Team. 2017. "Branch Campus Listing." C-BERT. http://cbert.org/resourcesdata/branch-campus/.

Franklin, Angela. and Alzouebi, Khadeegha. 2014. "Sustainability of International Branch Campuses in the United Arab Emirates: A Vision for the Future." The Journal of General Education 63(2): 121-137. https://doi.org/10.1353/jge.2014.0019.

Helms, Robin Matross. 2008. "Transnational Education in China: Key Challenges, Critical Issues and Strategies for Success." Observatory on Borderless Higher Education.

Hou, Angela Yung-Chi, Christopher Hill, Karen Hui Jung Chen, and Sandy Tsai. 2018. "A Comparative Study of International Branch Campuses in Malaysia, Singapore, China, and South Korea: Regulation, Governance, and Quality Assurance." Asia Pacific Education Review 19(4): 543-555. https://doi.org/10.1007/s12564-018-9550-9.

Huang, Futao. 2007. "Internationalization of Higher Education in the Developing and Emerging Countries: A Focus on Transnational Higher Education in Asia." Journal of Studies in International Education 11(3-4): 421-432. https://doi.org/10.1177/1028315307303919. 
O'Donnell, Victoria Louise. 2016. "Organisational Change and Development Towards Inclusive Higher Education." Journal of Applied Research in Higher Education 8(1): 101-118. https://doi.org/10.1108/JARHE-04-2014-0051.

Owen, Gregory T. 2014. "Qualitative Methods in Higher Education Policy Analysis: Using Interviews and Document Analysis." The Qualitative Report 19(26): 1-19. http://www.nova.edu/ssss/QR/QR19/owen52.pdf.

Redden, Elizabeth. 2019. "Wesleyan Won't Pursue China Campus." Inside Higher Ed, October 25, 2019. https://www.insidehighered.com/quicktakes/2019/10/25/wesleyan-wont-pursue-china-campus.

Shams, Farshid, and Jeroen Huisman. 2012. "Managing Offshore Branch Campuses: An Analytical Framework for Institutional Strategies." Journal of Studies in International Education 16(2): 106-127. https://doi.org/10.1177/1028315311413470.

Verbik, Line. 2007. "The International Branch Campus: Models and Trends." International Higher Education 46: 1415.

Wilkins, Stephen, and Jeroen Huisman. 2012. "The International Branch Campus as Transnational Strategy in Higher Education." Higher Education 64(5): 627-645. https://doi.org/10.1007/s10734-012-9516-5. 